\title{
Repetitive Transient Ischemia-Induced Cardiac Angiogenesis is Mediated by Camkii Activation
}

\author{
Zhuobin Chen $^{\mathrm{a}}$ Benlei Lia Qiaoqiao Dong ${ }^{\mathrm{a}} \quad$ Cheng Qian $^{\mathrm{a}}$ \\ Jun Cheng ${ }^{a}$ Yanggan Wanga,b \\ aDepartment of Cardiology, Zhongnan Hospital of Wuhan University, ${ }^{\text {b} M e d i c a l ~ R e s e a r c h ~ I n s t i t u t e ~ o f ~}$ \\ Wuhan University, Wuhan University, Wuhan, China
}

\section{Key Words}

Coronary angiogenesis $\cdot \mathrm{Ca}^{2+} /$ Calmodulin-dependent kinase II $\bullet$ Vascular endothelial growth factor • Ischemia

\begin{abstract}
Background/Aims: Coronary angiogenesis is an important protective mechanism in response to myocardial ischemia in coronary artery disease. However, the underlying mechanisms remain largely unclear. Here, we investigated the role of CaMKII activation in ischemiainduced cardiac angiogenesis. Methods: Repetitive transient ischemia model was established in C57/BL6 mice by daily multiple episodes ( 3 times/day) of short time (5 min) occlusion of the left anterior descending coronary artery for 7 days. Coronary angiogenesis was detected by immunofluorescent staining. RT-qPCR and Western blot analyses were used to detect the mRNA and protein levels of CaMKII, p-CaMKII and VEGF. Primary cardiac microvascular endothelial cells (CMECs) were isolated to investigate the effects of KN93 on cell proliferation and migration in hypoxic condition. Results: We found that angiogenesis was induced in the ischemic myocardium and suppressed by chronic intraperitoneal injection of CaMKII inhibitor KN93. RT-qPCR and Western blot analyses showed that myocardial ischemia induced an increased expression and autophosphorylation of CaMKII. VEGF expression was increased in the ischemia model but blunted by KN93. Moreover, KN93 suppressed the proliferation and migration of cardiac endothelial cells in hypoxic condition in which the protein expression of CaMKII, p-CaMKII and VEGF was increased. Conclusion: CaMKII is an important mediator for the ischemia-induced coronary angiogenesis, in which CaMKII-triggered VEGF expression plays a key role.
\end{abstract}




\section{Cellular Physiology Cell Physiol Biochem 2018;47:914-924 and Biochemistry Published online: May 29, $2018 \quad \begin{aligned} & \text { DOI: 10.1159/000490133 } \\ & \text { www.karger.com/cpb }\end{aligned}$ \\ Chen et al.: Camkii Mediates Ischemia-Induced Angiogenesis}

\section{Introduction}

Ischemic heart disease (IHD) is a primary cause of death in cardiovascular diseases [1] Although the prognosis has been significantly improved by percutaneous coronary intervention, there are still considerable patients who are not suitable for the intervention. Coronary angiogenesis is a compensatory coronary collateral vessel growth initiated by proliferation and migration of endothelial cells. Coronary angiogenesis significantly improves blood supply in the ischemic area, reduces the infarct size and mortality in patients with myocardial infarction [2-5]. Considerable studies have been conducted to investigate the mechanisms of coronary angiogenesis in order to develop better therapeutic strategies for IHD [6-8], but none of them showed promising effects in large clinical trials [9-11].

$\mathrm{Ca}^{2+} /$ Calmodulin-dependent kinase II (CaMKII) is excessively activated in IHD, which mediates the inflammation and ischemia/reperfusion damage $[12,13]$. Vascular endothelial growth factor (VEGF) is the vital stimulus for blood-vessel growth. Growing evidence showed that CaMKII activation may have potential connection with the increased expression of VEGF [14-16]. It has been demonstrated that CaMKII is capable of regulating the response of tumor to hypoxia via activating VEGF promoters [17]. However, whether CaMKII can stimulate VEGF expression and coronary angiogenesis in IHD has not yet been reported. Our aim is to decipher the role of CaMKII in mediating ischemia-induced angiogenesis in the heart.

\section{Materials and Methods}

\section{Repetitive transient ischemia murine model}

6 to 8-week-old male C57/BL6 mice at weight of 20-22g were used according to the protocol approved by the local Institutional Committee for Care and Use of Laboratory Animals (IACUC) at Zhongnan Hospital of Wuhan University, Wuhan. Mice were anesthetized with $1 \%$ sodium pentobarbital ( $80 \mathrm{mg} / \mathrm{kg}$ i.p), intubated, and mechanically ventilated. A mid line incision was made between the 2 nd and 3 rd ribs to expose the heart. To form a controllable occlusion, a 7-0 prolene suture was carefully passed through a $1 \mathrm{~mm}$ polyethylene tubing after threaded around the LAD area. Both ends of the suture were taken out of the thorax and fixed in a subcutaneous pocket. The skin was then closed with 5-0 prolene. Mice recovered from surgery for 3 days before ischemia experimentation. Coronary angiogenesis was then induced by episodes ( 3 times/day) of short time ( $5 \mathrm{~min}$ ) occlusion in the left anterior descending artery for consecutive 7 days. The sham group underwent the same procedures except placing tension on the suture ends. The ischemia group underwent repetitive ischemia (transient LAD occlusion). CaMKII inhibitor KN93 and its inactive analogue KN92 were used to inhibit CaMKII and as a negative control of KN93, respectively. In the ischemia + KN93 or KN92 (Calbiochem) group, KN93 or KN92 $(10 \mu \mathrm{mol} / \mathrm{kg}$, i.p. daily) was given prior to LAD occlusion to produce chronic CaMKII inhibition.

\section{ECG recording}

To determine successful ischemia induction, the limb leads ECG (Powerlab instrument PL3516B49, Labchart 7.0 software) was recorded in the conscious mice. ST-segment elevation in leads I and aVL was observed when placing tension in the suture and returning to the baseline when loosing the suture, indicating establishment of an onset of ischemia.

\section{Echocardiography in conscious mice}

Cardiac function was measured in conscious mice by Vevo 2100 system with a MX400 (18-38MHz) transducer. Left ventricular (LV) dimensions at diastole and systole (LVDd, LVDs) were measured digitally from the M-mode tracings. Based on these measurements, LV systolic volume (LVVs) was calculated as [7.0/ $(2.4+\mathrm{LVDs})] \times \mathrm{LVDs}^{3}, \mathrm{LV}$ diastolic volume (LVVd) was calculated as $[7.0 /(2.4+\mathrm{LVDd})] \times \mathrm{LVDd}^{3}$, ejection fraction (EF) \% was calculated as $\left[\left(\right.\right.$ LVIDd $^{3}-$ LVIDs $\left.^{3}\right) /$ LVIDd $\left.^{3}\right] \times 100$, Fractional shortening (FS) \% was calculated as (LVIDd-LVIDs)/LVIDd×100, stroke volume (SV) was calculated as LVVd-LVVs. Parameters were measured and calculated before ischemia intervention as a baseline, then every other day during the periodic ischemia for 7 days. 


\section{Cellular Physiology Cell Physiol Biochem 2018;47:914-924 \begin{tabular}{l|l} 
and Biochemistry Published online: May 29, 2018 & $\begin{array}{l}\text { D } 2018 \text { The Author(s). Published by S. Karger AG, Basel } \\
\text { www.karger.com/cpb }\end{array}$ \\
\hline
\end{tabular} \\ Chen et al.: Camkii Mediates Ischemia-Induced Angiogenesis}

Immunohistochemistry analysis

Microvessel density (MVD) was assessed by CD31 immunofluorescent staining while endothelial cell proliferation was enumerated via double staining with the proliferation marker Ki67. Left ventricles from sham, ischemia and ischemia + KN93/KN92 mice were isolated at the end of experiments (day 7). Slides were treated with primary antibodies, including rat antiCD31/PECAM 1:200 (BD) and rabbit anti-Ki67 1:200 (Santa Cruz Biotechnology). The secondary antibodies include rat anti-Cy3-conjugated antibody 1:300 (Goodbio technology) and rabbit anti-FITC-conjugated antibody 1:300 (Goodbio technology). The nuclei were labeled with $0.1 \mathrm{mg} / \mathrm{ml}$ DAPI (Goodbio technology). Images were acquired using fluorescence microscope (Nikon Eclipse Ti-SR). Angiogenesis index was determined as the ratio of the numbers of microvessels to the DAPI positive cells (CD31:DAPI). Cellular proliferation index was calculated as the ratio of Ki67 staining cells to the DAPI positive cells (Ki67:DAPI). Both of them were quantified at least in 4 independent fields from each heart.

\section{Quantitative RT-PCR}

RNA was isolated using Trizol (Invitrogen Life Technologies). cDNA was synthesized using the RevertAid First Strand cDNA Synthesis Kit (Thermo). Quantitative RT-PCR was performed by Applied Biosystems 7300 real Time PCR using SYBR green (Roche) based assay. Quantitative RT-PCR was performed with the specific primers shown in Table 1.

\section{Western-blot}

The isolated LV tissues or cultured cells were homogenized as described [18]. Primary antibodies used in this study include rabbit polyclonal anti-CaMKII antibody, rabbit polyclonal anti-phospho-CaMKII (Thr287) antibody, rabbit monoclonal anti-GAPDH antibody (Cell signaling technology), rabbit polyclonal anti-VEGF antibody (Santa Cruz Biotechnology) and rabbit polyclonal anti-CD31 antibody (Abcam). The second antibody used was goat anti-rabbit IgG-HRP (Santa Cruz Biotechnology).

\section{Isolation, culture and identification of primary Cardiac Microvascular Endothelial Cells (CMECs)}

Isolation of CMECs was performed according to the published protocol [19]. Briefly, 6 neonatal Sprague-Dawley rat hearts were isolated and dissected into $\approx 1 \mathrm{~mm}^{3}$ pieces and then digested by addition of $0.1 \%$ collagenase B (Roche) for $30 \mathrm{~min}$ and $0.25 \%$ Tyrisin-EDTA (hyclone) for $10 \mathrm{~min}$ at $37^{\circ} \mathrm{C}$. After filtration and centrifugation, cells were resuspended with 20\% Fetal Bovine Serum (gbico)-M199 medium (hyclone) and $50 \mu \mathrm{g} / \mathrm{ml}$ heparin. $75 \mu \mathrm{g} / \mathrm{ml}$ endothelial cell growth supplement (BD) was added to provide the best microenvironment for endothelial cells. CMECs were identified by microscope and CD31 immunofluorescent staining.

\section{CMECs proliferation assay}

The CMECs $\left(5 \times 10^{3}\right.$ cells/well) were cultured in 96-well plates overnight. The media was replaced

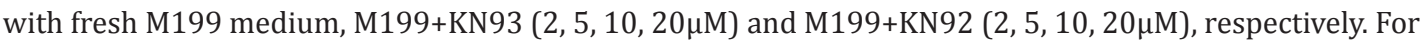
hypoxia group, cells were incubated with $3 \% \mathrm{O}_{2}$, while the cells in normoxia group were incubated with $20 \%$ $\mathrm{O}_{2}$ at $37^{\circ} \mathrm{C}$ for 24 hours. At the end of the indicated time-periods, cell proliferation was measured using a cell counting Kit-8 (CCK-8 kit; Dojindo Molecular Technologies) according to the manufacturer's instructions. The inhibition rate of cell proliferation was calculated by the following formula: Inhibition rate (IR\%) = $(1$ $\left.\mathrm{OD}_{\text {experimental group }} / \mathrm{OD}_{\text {control group }}\right) \times 100$

\section{CMECs migration assay}

Cell mobility was assessed using the transwell assay (Corning Inc. Corning, NY, USA). CMEC cells $\left(4 \times 10^{4}\right.$ per well, treated with $2 \mu \mathrm{M}$ KN93, KN92 or blank control medium) were seeded in the upper wells with serum-free medium. Medium with 20\% FBS was added into the bottom wells to act as a chemoattractant. 


\section{Cellular Physiology Cell Physiol Biochem 2018;47:914-924 and Biochemistry Published online: May 29, $2018 \quad \begin{aligned} & \text { DOI: 10.1159/000490133 } 2018 \text { The Author(s). Published by S. Karger AG, Basel } \\ & \text { www.karger.com/cpb }\end{aligned}$ \\ Chen et al.: Camkii Mediates Ischemia-Induced Angiogenesis}

Cells in the hypoxia groups were incubated with $3 \% \mathrm{O}_{2}$, while cells in the normoxia groups were incubated with $20 \% \mathrm{O}_{2}$ at $37^{\circ} \mathrm{C}$. After 12 hours of incubation, the cells were washed with PBS for 3 times and fixed with $4 \%$ paraformaldehyde for $30 \mathrm{~min}$, then stained with $1 \%$ crystal violet for $15 \mathrm{~min}$ at $37^{\circ} \mathrm{C}$. The cells on the upper chamber were removed by cotton swab, the migrated cells counting was then performed under microscope (Nikon Eclipse Ti-SR). Five random views were selected to count the migrated cells.

\section{Statistical analysis}

Statistical tests were performed using GraphPad Prism software (version 5.0). Statistical significance was evaluated using independent-sample $t$-test for comparison between 2 groups and one-way ANOVA with Dunnett's post test for comparison among 3 or more groups. Echocardiographic and morphometric data were reported as mean \pm standard deviation, while other data were shown as mean \pm SEM. $p$ value less than 0.05 was considered statistically significant.

\section{Results}

\section{Establishment of coronary angiogenesis model induced by repetitive ischemia}

We performed a closed-chest ischemia/reperfusion (I/R) to induce repetitive transient cardiac ischemia in mice. Echocardiographic and morphometric data during myocardial ischemia are summarized in Table 2 . The left ventricular function assessed by EF (\%) remained constant after ischemic performance, indicating that the repetitive ischemia did not cause myocardial necrosis. ECG monitoring was conducted during each ischemia application to verify a successful induction of ischemia. ST segment was elevated during each onset of ischemia and recovered afterwards (Fig. 1), indicating that each episode resulted in an ischemic attack, i.e. the repetitive I/R model was well established.

Role of CaMKII activity in the I/R-induced cardiac angiogenesis

To determine whether CaMKII activation is associated with the I/R-induced cardiac angiogenesis, the immunofluorescent staining and Western blot against CD31 were performed and quantified in the ischemic myocardium 7 days after daily I/R. As shown in Fig. 2, the capillary densities in the LV myocardium in both ischemia and ischemia + KN92 groups were significantly increased

Table 2. Echocardiographic and morphometric parameters monitored during periodic ischemia. Values are mean \pm standard deviation. LVID: left ventricular internal dimension, EF: ejection fraction, FS: fractional shortening, SV: stroke volume, BW: body weight, HW: heart weight, s: systolic, d: diastolic, n: sample size in each group

\begin{tabular}{llllll}
\hline Parameter & Day 0 & Day 1 & Day 3 & Day 5 & Day 7 \\
& & & \multicolumn{2}{c}{$(\mathrm{n}=20)$} \\
LVIDd(mm) & $3.4 \pm 0.4$ & $3.3 \pm 0.2$ & $3.5 \pm 0.3$ & $3.4 \pm 0.3$ & $3.5 \pm 0.3$ \\
LVIDs(mm) & $1.5 \pm 0.2$ & $1.7 \pm 0.1$ & $1.5 \pm 0.2$ & $1.5 \pm 0.2$ & $1.7 \pm 0.2$ \\
EF(\%) & $89.5 \pm 5.8$ & $86.9 \pm 3.5$ & $91.3 \pm 3.9$ & $90.3 \pm 6.6$ & $88.2 \pm 4.9$ \\
FS(\%) & $54.7 \pm 9.4$ & $49.2 \pm 5.1$ & $56.8 \pm 6.9$ & $56.0 \pm 9.3$ & $51.8 \pm 6.6$ \\
SV(uL) & $43.9 \pm 14$ & $38.6 \pm 6.9$ & $46.9 \pm 8.5$ & $44.7 \pm 12.3$ & $44.2 \pm 10.8$ \\
BW(g) & $21.2 \pm 0.4$ & $20.8 \pm 0.9$ & $20.9 \pm 0.9$ & $21 \pm 0.6$ & $21 \pm 0.7$ \\
HW/BW(mg/g) & $5 \pm 0.4$ & $5.3 \pm 0.6$ & $5.3 \pm 0.6$ & $5.6 \pm 0.3$ & $5.4 \pm 0.2$
\end{tabular}
compared to the shamoperated controls. However, the angiogenesis was eliminated in mice treated with daily intraperitoneal injection of CaMKII inhibitor KN93. In addition to the inhibition of capillary density, KN93 also blunted cellular proliferation (Ki67/ DAPI ratio). These results suggested that CaMKII

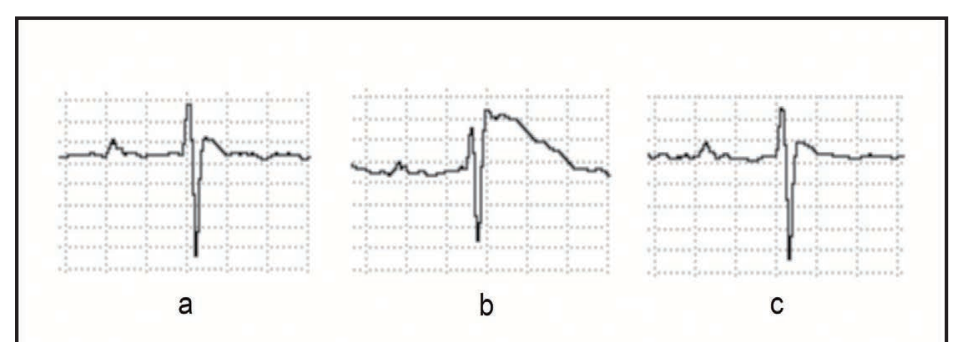

Fig. 1. Changes of ECG at lead I before (a) during (b) and after (c) each brief ischemia episode. ST segment was elevated during ischemia and fell back after reperfusion. 
activation plays a key role in the repetitive ischemiainduced angiogenesis.

CaMKII inhibition
abrogated VEGF
expression in the
ischemic myocardium
To explore the
underlying mechanism of coronary angiogenesis induced by ischemia, the mRNA levels of CaMKII and VEGF at the ischemic day $0,1,3,5,7$ were detected by RT-qPCR. As shown in Fig. 3, the mRNA level of CaMKII increased significantly and reached a peak after 5 days ischemia in both ischemia (Fig. 3A), ischemia + KN92 (Fig. 3B) and ischemia + KN93 group (Fig. 3C). In contrast, VEGF mRNA level was increased in the ischemia and ischemia + KN92 groups but not in the ischemia + KN93 group. These results indicated that the repetitive ischemia induced CaMKII and VEGF expression while the VEGF expression was mediated by CaMKII activation. Coincide well with the RT-qPCR results, the phosphorylation level of CaMKII, expression of CaMKII and VEGF gradually increased with the ischemia episode. Injection of KN93 blocked phosphorylation of CaMKII and downregulated the protein level of VEGF without changes in the expression of CaMKII (Fig. 4). These data demonstrated that the repetitive ischemia triggers coronary angiogenesis through the activation of CaMKII-VEGF pathway.

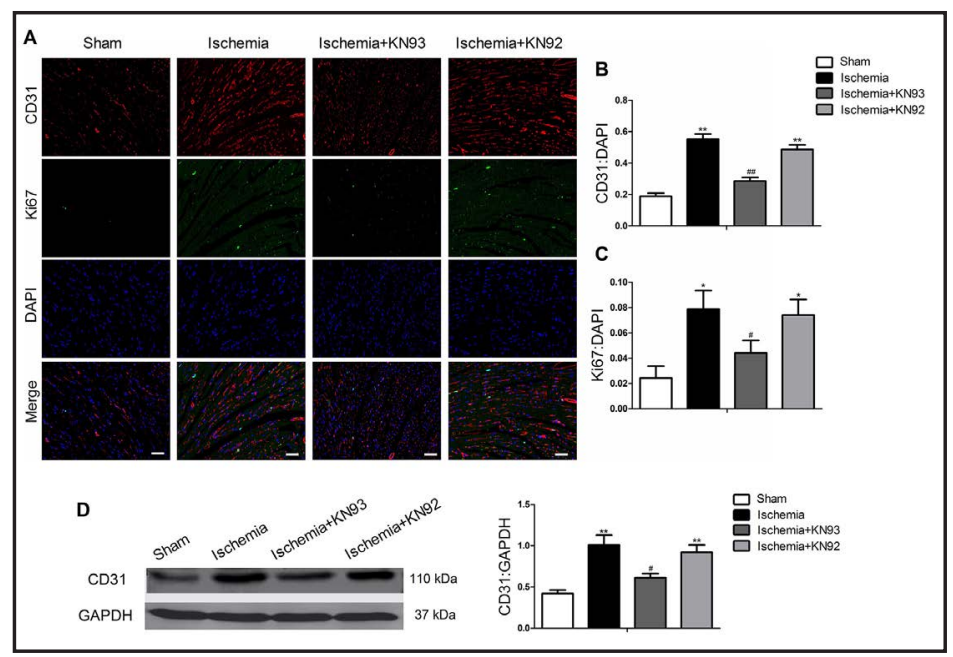

Fig. 2. Coronary angiogenesis detected using immunofluorescence. A: CD31/PECAM and Ki67 double-staining immunofluorescent images in sham, ischemia, ischemia + KN93, ischemia + KN92 groups. Scale bar $=50 \mu \mathrm{m}$. B\&C: Quantification of angiogenesis and proliferation index, showing that the increase in capillary density and endothelial cellular proliferation by ischemia can be prevented by CaMKII inhibitor KN93. D: Western blot analysis for CD31 expression in heart. The analysis data were from 6 mice. *: $\mathrm{P}<0.05$, **: $\mathrm{P}<0.01$ compared with sham group. \#: $\mathrm{P}<0.05$, \#\#: $\mathrm{P}<0.01$ compared with ischemia group. $\mathrm{PECAM}$ : platelet endothelial cell adhesion molecule.

Fig. 3. Analysis of RT-qPCR in ischemia (A), ischemia + KN92 (B) and ischemia + KN93 (C) groups. CaMKII and VEGF mRNA levels measured at day $0,1,3,5$, and 7 of periodic ischemia. CaMKII levels increased after ischemia and peaked after 5 days ischemia in the ischemia, ischemia + KN92, and ischemia + KN93 group. VEGF expression increased in the

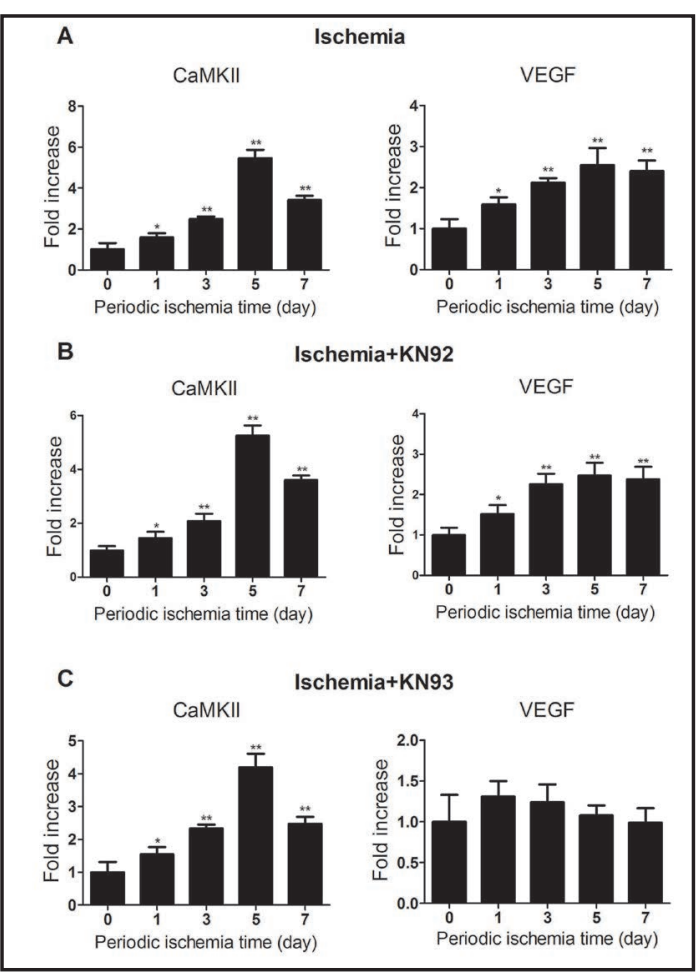
ischemia and ischemia + KN92 groups but unchanged in the ischemia + KN93 group. All values are mean \pm SEM from 5 independent experiments. *: $\mathrm{p}<0.05,{ }^{* *}$ : $\mathrm{p}<0.01$ compared with Day 0 . 
Fig. 4. Protein expression levels of CaMKII, p-CaMKII and VEGF in the ischemia, ischemia + KN93 and ischemia + KN92 groups measured at day $0,1,3,5$, and 7 of periodic ischemia. CaMKII expression gradually increased in all groups. Phosphorylation level of CaMKII and VEGF increased remarkably in the ischemia and ischemia + KN92 groups. CaMKII inhibition by KN93 eliminated the ischemia-induced VEGF expression. Data presented as mean \pm SEM were from 5 independent experiments. *: $\mathrm{P}<0.05$, **: $\mathrm{P}<0.01$ compared with Day 0 .

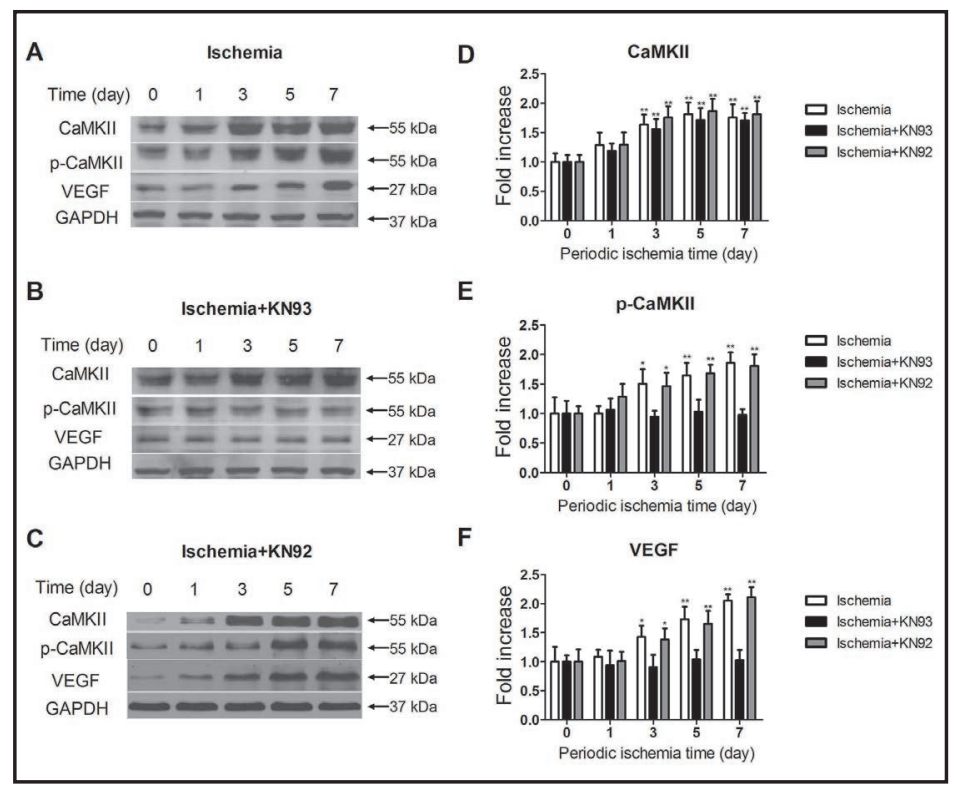

Table 3. The effect of KN92 on CMEC proliferation. Data were from 6 independent experiments and expressed as mean \pm SEM

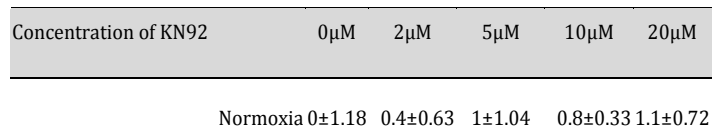

Inhibition rate $(\%)$

Hypoxia $0 \pm 1.17 \quad 0.2 \pm 1.73 \quad 0.1 \pm 1.94 \quad 0.1 \pm 0.381 .5 \pm 0.51$

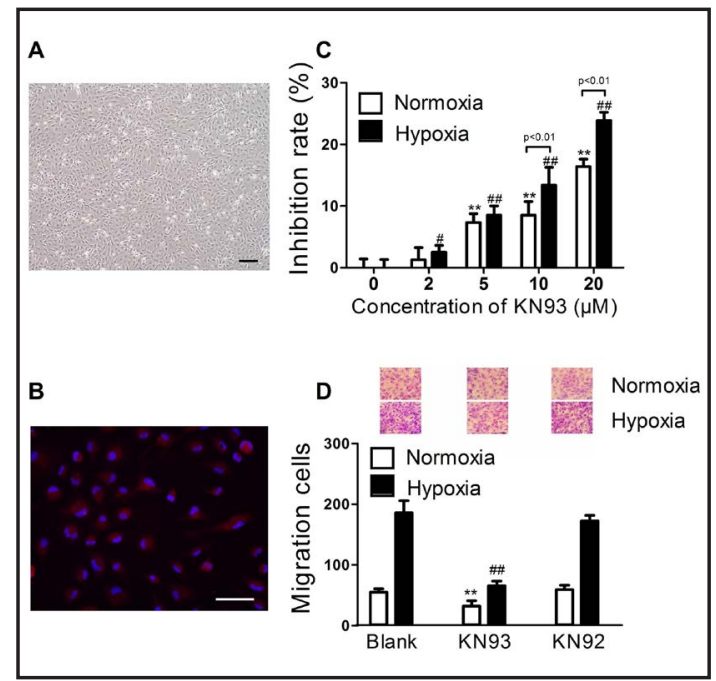
concentration-de-

Fig. 5. KN93 inhibited the proliferation and migration of CMECs in vitro. CMECs were isolated (A) and then identified by CD31 immunofluorescent staining (B). Scale bar = $50 \mu \mathrm{m}$. The CCK-8 assay was conducted to reflect the proliferation of CMECs indirectly (C). KN93 inhibited the CMEC proliferation in a pendent manner with a greater inhibition in the hypoxia than the normoxia condition. Migration of CMECs was inhibited by CaMKII inhibitor KN93 but not by its inactive analogue KN92 (D). Data were from 6 independent experiments and expressed as mean \pm SEM. **: $\mathrm{P}<0.01$, compared with blank medium group in normoxia condition. \#\#: $\mathrm{P}<0.01$, compared with blank medium group in hypoxia condition.
, $5 \mu \mathrm{M}$, and $20 \mu \mathrm{M}$ KN93, respectively) and 


\section{Cellular Physiology Cell Physiol Biochem 2018;47:914-924 \begin{tabular}{l|l} 
DOI: 10.1159/000490133 & O 2018 The Author(s). Published by S. Karger AG, Basel \\
www.karger.com/cpb
\end{tabular}

Fig. 6. Hypoxia-induced VEGF expression was suppressed by CaMKII inhibition. A: Representative Western blots showing expression of CaMKII, p-CaMKII and VEGF in CMECs. B: Analysis of protein levels of CaMKII, p-CaMKII and VEGF in CMECs in the condition of hypoxia and normoxia with treatment of KN93 or KN92, respectively. Data were from 6 independent experiments and expressed as mean \pm SEM. $*$ : $\mathrm{P}<0.05$, **: $\mathrm{P}<0.01$ compared with normoxia, \#: $\mathrm{P}<0.05$, \#\#: $\mathrm{P}<0.01$ compared with hypoxia.

hypoxia $(\mathrm{IR} \%=2.5 \pm 1.1,8.5 \pm 1.5, \quad 13.4 \pm 2.9$, $23.9 \pm 1.3$ for $2 \mu \mathrm{M}, 5 \mu \mathrm{M}, 10 \mu \mathrm{M}$ and $20 \mu \mathrm{M}$ KN93, respectively) groups, with a much greater inhibition rate in the hypoxia group. We further explored the effect of KN93 on CMEC migration by transwell assay. As shown in Fig. 5D, hypoxia induced remarkable increase

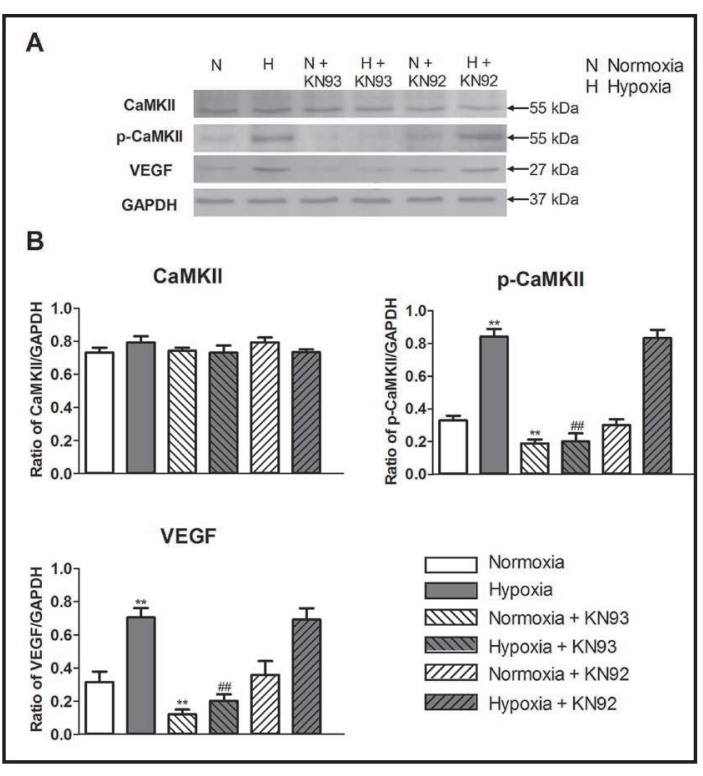
in cell migration $(53.8 \pm 5.9$ vs $185.9 \pm 19.9$, $\mathrm{p}<0.01)$. As expected, $2 \mu \mathrm{M}$ KN93 dramatically suppressed CMEC migration $(185.9 \pm 19.9$ vs $65.7 \pm 7.8, \mathrm{p}<0.01$ ). These results demonstrated that CaMKII plays a key role in regulating the proliferation and migration of cardiac microvascular endothelial cells.

\section{CaMKII inhibition attenuated VEGF expression in CMECs}

We have detected the protein levels of CaMKII, p-CaMKII and VEGF in CMECs. As shown in Fig. 6, the levels of phosphorylated CaMKII and VEGF expression were increased after 24 hours hypoxia, but this increase has been attenuated by KN93. Interestingly, KN93 also reduced the basal VEGF protein level, indicating that a basal level of CaMKII activity is required to maintain VEGF expression in the normoxic condition. The total CaMKII expression did not change in hypoxic condition. Unlike KN93, KN92 had no effects on the expression of CaMKII, p-CaMKII and VEGF.

\section{Discussion}

In this study, we have demonstrated that (1) the periodic transient ischemia-induced significant coronary angiogenesis with increased expression levels of CaMKII, p-CaMKII and VEGF in the ischemic myocardium. (2) CaMKII inhibition by KN93 down-regulated the expression of VEGF and thus inhibited the ischemia-induced coronary angiogenesis. (3) In line with the in vivo results, CaMKII inhibition suppressed CMEC proliferation and migration in hypoxia condition. (4) Ischemia increased CaMKII expression in myocardium but not in the endothelial cells.

CaMKII is a known pro-arrhythmic molecule and a key mediator of heart failure [20,21]. CaMKII also participated in artery remodeling through vascular smooth muscle cells [22]. In the present study, we have revealed an important role of CaMKII activation in the ischemiainduced coronary angiogenesis. Previous studies have reported that chronic ischemia has a direct association with coronary angiogenesis, but the underlying molecular mechanisms are unclear [23, 24]. It has been shown that CaMKII inhibition blunted tumor response to hypoxia [17] and that CaMKII is likely the upstream signal of the hypoxia inducible factor-1 alpha (HIF-1 $\alpha$ ) in macrophage and some cancer cell lines [14-16]. Indeed, oxidative stress and calcium entry caused by repetitive ischemia can both activate CaMKII [25-27]. Our experiment showed a clear association between CaMKII activation and coronary angiogenesis induced by repetitive ischemia. CaMKII inhibition by KN93 abrogated the ischemia-induced 
CaMKII activation, down-regulated VEGF expression and eliminated coronary angiogenesis. However, KN93 did not decline cardiac function in mice subjected to the repetitive ischemia (data not shown). A possible explanation is that in the setting of ischemia, cardiac CaMKII is excessively activated, which stimulates cardiac angiogenesis to improve cardiac perfusion but meanwhile reduces myocyte function (by inducing sarcoplasmic reticulum calcium leak $[18,28])$. A myocyte-specific CaMKII inhibition is therefore desirable.

VEGF is a known key mediator for the ischemia-induced angiogenesis. Previous studies have demonstrated that VEGF expression is essential in coronary collateral growth [29, 30]. VEGF gene delivery increased microvascular density in the myocardial infarct zone [8]. The primary promoters of VEGF are HIF- $1 \alpha$ and activating protein-1 (AP-1). CaMKII was able to up-regulate the expression of HIF- $1 \alpha$ in marcrophage [14] and retinal Müller cells [31], and increase AP-1 protein level in osteosarcoma [15]. However, there was study showed that CaMKII inhibitor had no effect on HIF-1 $\alpha$ induced VEGF production in rheumatoid synovial fibroblast [32]. In hepatoma cells, CaMKII has been shown to up-regulate VEGF expression directly [16]. Interestingly, in hippocampal neurons and retinal endothelial cells, CaMKII was activated by VEGF via increasing $\mathrm{Ca}^{2+}$ influx [33-35]. In consistent with this, our data indicated that inhibition of CaMKII decreased expression of VEGF and suppressed CMECs proliferation and migration and in vivo coronary angiogenesis. These findings suggested that CaMKII activation promotes coronary angiogenesis likely through up-regulating VEGF. In fact, increasing of VEGF expression was detected in limb ischemia, [36] experimental MI [37] and ischemia-induced coronary collateral growth models $[29,30]$ However, in a mouse model of coronary ischemia established by Lavine et al [38]., neither mRNA nor protein level of VEGF increased. We speculate that this inconsistency may be related to the stimulus frequency and duration of ischemia. In Kory's model, ischemia was induced by only 3 ischemia episodes in a week, while we established a model by 5 minutes ischemia per 8 hours for one week. This pattern avoids myocardial necrosis and ensures a frequent onset of hypoxia to stimulate the VEGF expression. Moreover, this chronic repetitive transient ischemia is more close to the clinical stable angina caused by coronary stenosis.

Stimulation of coronary collateral formation provides a broad prospect for the treatment of CAD patients [39-41]. Various therapeutic angiogenesis attempts focused on VEGF and FGF to induce coronary collateral growth have been reported in recent decades $[10,42,43]$, but none of them really works in the patients. Our findings revealed a novel mechanism underlying the repetitive ischemia-induced coronary angiogenesis which highlight the important role of CaMKII herein.

In this study, we have demonstrated that microvascular density was significantly reduced by inhibition of CaMKII activation. However, even treated with KN93, coronary angiogenesis has not been fully suppressed, indicating that other signal pathways may also be involved in coronary angiogenesis. In addition, the expression of CaMKII didn't change during hypoxia in vitro, but increased markedly in the ischemic myocardium. This finding indicates that besides CMECs, myocardial environment may be important for coronary angiogenesis. For instance, the increase in CaMKII activity, as a key trigger of ischemia-induced coronary angiogenesis, may largely derive from the ischemic myocardium.

\section{Conclusion}

Our data revealed a novel mechanism for the coronary angiogenesis. Chronic repetitive ischemia induces CaMKII activation which triggers VEGF expression and thereby promotes coronary angiogenesis.

\section{Acknowledgements}

This work was supported by grants from the National Natural Science Foundation of China to Wang Y [NSFC 81270304 and NSFC 81420108004]. 


\section{Cellular Physiology Cell Physiol Biochem 2018;47:914-924

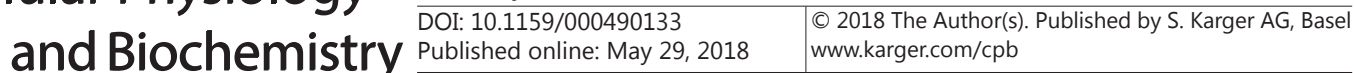 \\ Chen et al.: Camkii Mediates Ischemia-Induced Angiogenesis}

Y.W. and J.C. conceived and designed the project and experiments. Z.C. performed the experiments. Z.C., Q.D. and C.Q. analyzed the data. Z.C., B.L. and Y.W. wrote and revised the paper. All authors reviewed the manuscript.

\section{Disclosure Statement}

The authors declare no competing financial interests.

\section{References}

1 Mozaffarian D, Benjamin EJ, Go AS, Arnett DK, Blaha MJ, Cushman M, Das SR, de Ferranti S, Després JP, Fullerton HJ, Howard VJ, Huffman MD, Isasi CR, Jiménez MC, Judd SE, Kissela BM, Lichtman JH, Lisabeth LD, Liu S, Mackey RH, Magid DJ, McGuire DK, Mohler ER 3rd, Moy CS, Muntner P, Mussolino ME, Nasir K, Neumar RW, Nichol G, Palaniappan L, Pandey DK, Reeves MJ, Rodriguez CJ, Rosamond W, Sorlie PD, Stein J, Towfighi A, Turan TN, Virani SS, Woo D, Yeh RW, Turner MB: Executive summary heart disease and stroke statistics 2016 update: a report from the american heart association. Circulation 2016;133:447-454.

-2 Steg PG, Kerner A, Mancini GB, Reynolds HR, Carvalho AC, Fridrich V, White HD, Forman SA, Lamas GA, Hochman JS, Buller CE: Impact of collateral flow to the occluded infarct-related artery on clinical outcomes in patients with recent myocardial infarction. A report from the randomized occluded artery trial. Circulation 2010;121:2724-2730.

3 Meier P, Hemingway H, Lansky AJ, Knapp G, Pitt B, Seiler C: The impact of the coronary collateral circulation on mortality: a meta-analysis. Eur Heart J 2012;33:614-621.

4 Robich MP, Chu LM, Oyamada S, Sodha NR, Sellke FW: Myocardial therapeutic angiogenesis: a review of the state of development and future obstacles. Expert Rev Cardiovasc Ther 2011;9:1469-1479.

-5 Smart N, Dubé KN, Riley PR: Coronary vessel development and insight towards neovascular therapy. Int J Exp Pathol 2009;90:262-283.

6 Rubanyi GM: Identifying and overcoming obstacles in angiogenic gene therapy for myocardial ischemia. J Cardiovasc Pharmacol 2014;64:109-119.

7 Kastrup J: Gene therapy and angiogenesis in patients with coronary artery disease. Expert Rev Cardiovasc Ther 2010;8:1127-1138.

8 Uitterdijk A, Springeling T, van Kranenburg M, van Duin RW, Krabbendam-Peters I, Gorsse-Bakker C, Sneep S, van Haeren R, Verrijk R, van Geuns RJ, van der Giessen WJ, Markkula T, Duncker DJ, van Beusekom HM: VEGF165A Microsphere therapy for myocardial infarction suppresses acute cytokine release and increases microvascular density but does not improve cardiac function. Am J Physiol Heart Circ Physiol 2015;309:H396-H406.

-9 Rubanyi GM: Mechanistic, technical, and clinical perspectives in therapeutic stimulation of coronary collateral development by angiogenic growth factors. Mol Ther 2013;21:725-738.

10 Gupta R, Tongers J, Losordo DW: Human studies of angiogenic gene therapy. Circ Res 2009;105:724-736.

$>11$ Kusumanto YH, van Weel V, Mulder NH, Smit AJ, van den Dungen JJ, Hooymans JM, Sluiter WJ, Tio RA, Quax PH, Gans RO, Dullaart RP, Hospers GA: Treatment with intramuscular vascular endothelial growth factor gene compared with placebo for patients with diabetes mellitus and critical limb ischemia a double-blind randomized trial. Hum Gene Ther 2006;17:683-691.

$>12$ Ling H, Gray CB, Zambon AC, Grimm M, Gu Y, Dalton N, Purcell NH, Peterson K, Brown JH: Ca2+/ Calmodulin-dependent protein kinase II delta mediates myocardial ischemia/reperfusion injury through nuclear factor-kappaB. Circ Res 2013;112:935-944.

13 Bell JR, Vila-Petroff M, Delbridge LM: CaMKII-dependent responses to ischemia and reperfusion challenges in the heart. Front Pharmacol 2014;5:96.

14 Westra J, Brouwer E, van Roosmalen IA, Doornbos-van der Meer B, van Leeuwen MA, Posthumus MD, Kallenberg CG: Expression and regulation of HIF-1alpha in macrophages under inflammatory conditions; significant reduction of VEGF by CaMKII inhibitor. BMC Musculoskelet Disord 2010;11:61-72.

15 Daft PG, Yang Y, Napierala D, Zayzafoon M: The growth and aggressive behavior of human osteosarcoma is regulated by a CaMKII-controlled autocrine VEGF signaling mechanism. PLoS One 2015;10:e0121568. 


\section{Cellular Physiology Cell Physiol Biochem 2018;47:914-924 \begin{tabular}{l|l} 
and Biochemistry Published online: May 29, 2018 & $\begin{array}{l}\text { D } 2018 \text { The Author(s). Published by S. Karger AG, Basel } \\
\text { www.karger.com/cpb }\end{array}$
\end{tabular}}

Chen et al.: Camkii Mediates Ischemia-Induced Angiogenesis

16 Liu ZN, Dai HL, Jia GZ, Li YH, Liu X, Ren WD: Insufficient radiofrequency ablation promotes human hepatoma SMMC7721 cell proliferation by stimulating vascular endothelial growth factor overexpression. Oncol Lett 2015;9:1893-1896.

$\checkmark 17$ Lee KH: CaMKII Inhibitor KN-62 blunts tumor response to hypoxia by inhibiting HIF-1alpha in hepatoma cells. Korean J Physiol Pharmacol 2010;14:331-336.

18 Cheng J, Xu L, Lai D, Guilbert A, Lim HJ, Keskanokwong T, Wang Y: CaMKII inhibition in heart failure, beneficial, harmful, or both. Am J Physiol Heart Circ Physiol 2012;302:H1454-H1465.

19 Marelli-Berg FM, Peek E, Lidington EA, Stauss HJ, Lechler RI: Isolation of endothelial cells from murine tissue. J Immunol Methods 2000;244:205-215.

-20 Zhang T, Brown JH: Role of ca2+/calmodulin-dependent protein kinase II in cardiac hypertrophy and heart failure. Cardiovasc Res 2004;63:476-486.

-21 Anderson ME: Calmodulin kinase signaling in heart: an intriguing candidate target for therapy of myocardial dysfunction and arrhythmias. Pharmacol Ther 2005;106:39-55.

22 Scott JA, Klutho PJ, El Accaoui R, Nguyen E, Venema AN, Xie L, Jiang S, Dibbern M, Scroggins S, Prasad AM, Luczak ED, Davis MK, Li W, Guan X, Backs J, Schlueter AJ, Weiss RM, Miller FJ, Anderson ME, Grumbach IM: The multifunctional $\mathrm{Ca}(2)(+) /$ calmodulin-dependent kinase IIdelta (CaMKIIdelta) regulates arteriogenesis in a mouse model of flow-mediated remodeling. PLoS One 2013;8:e71550.

23 Tian X, Pu WT, Zhou B: Cellular origin and developmental program of coronary angiogenesis. Circ Res 2015;116:515-530.

24 Lam YT: Critical roles of reactive oxygen species in age-related impairment in ischemia-induced neovascularization by regulating stem and progenitor cell function. Oxid Med Cell Longev 2015;2015:7095901.

25 Hudmon A, Schulman H: Structure-function of the multifunctional ca2+calmodulin-dependent protein kinase II. Biochem J 2002;364:593-611.

-26 Erickson JR, Joiner ML, Guan X, Kutschke W, Yang J, Oddis CV, Bartlett RK, Lowe JS, O’Donnell SE, AykinBurns N, Zimmerman MC, Zimmerman K, Ham AJ, Weiss RM, Spitz DR, Shea MA, Colbran RJ, Mohler PJ, Anderson ME: A dynamic pathway for calcium independent activation of CaMKII by methionine oxidation. Cell 2008;133:462-74.

27 Vittone L, Mundiña-Weilenmann C, Said M, Ferrero P, Mattiazzi A.: Time course and mechanisms of phosphorylation of phospholamban residues in ischemia-reperfused rat hearts. Dissociation of phospholamban phosphorylation pathways. J Mol Cell Cardiol 2002;34:39-50.

28 Picht E, DeSantiago J, Huke S, Kaetzel MA, Dedman JR, Bers DM: CaMKII inhibition targeted to the sarcoplasmic reticulum inhibits frequency-dependent acceleration of relaxation and Ca2+ current facilitation. J Mol Cell Cardiol. 2007;42:196-205.

29 Matsunaga T, Warltier DC, Weihrauch DW, Moniz M, Tessmer J, Chilian WM: Ischemia-induced coronary collateral growth is dependent on vascular endothelial growth factor and nitric oxide. Circulation 2000;102:3098-3103.

-30 Toyota E, Warltier DC, Brock T, Ritman E, Kolz C, O’Malley P, Rocic P, Focardi M, Chilian WM: Vascular endothelial growth factor is required for coronary collateral growth in the rat. Circulation 2005;112:21082113.

-31 Li J, Zhao SZ, Wang PP, Yu SP, Zheng Z, Xu X: Calcium mediates high glucose-induced HIF-1alpha and VEGF expression in cultured rat retinal Müller cells through CaMKII-CREB pathway. Acta Pharmacol Sin 2012;33:1030-1036.

-32 Westra J, Brouwer E, Bouwman E, Doornbos-van der Meer B, Posthumus MD, van Leeuwen MA, Limburg PC, Ueda Y, Kallenberg CG: Role for CaMKII inhibition in rheumatoid arthritis: effects on HIF-1-induced VEGF production by rheumatoid synovial fibroblasts. Ann N Y Acad Sci 2009;1173:706-11.

33 Kim BW, Choi M, Kim YS, Park H, Lee HR, Yun CO, Kim EJ, Choi JS, Kim S, Rhim H, Kaang BK, Son H: Vascular endothelial growth factor (VEGF) signaling regulates hippocampal neurons by elevation of intracellular calcium and activation of calcium/calmodulin protein kinase II and mammalian target of rapamycin. Cell Signal 2008;20:714-725.

-34 Banumathi E, O'Connor A, Gurunathan S, Simpson DA, McGeown JG, Curtis TM: VEGF-induced retinal angiogenic signaling is critically dependent on $\mathrm{Ca} 2+$ signaling by $\mathrm{Ca} 2+/$ Calmodulin-dependent protein kinase II. Invest Ophthalmol Vis Sci 2011;52:3103-3111. 


\section{Cellular Physiology Cell Physiol Biochem 2018;47:914-924 \begin{tabular}{l|l} 
DOI: 10.1159/000490133 & O 2018 The Author(s). Published by S. Karger AG, Basel \\
www.karger.com/cpb
\end{tabular} \\ Chen et al.: Camkii Mediates Ischemia-Induced Angiogenesis}

-35 De Bock M, Wang N, Decrock E, Bol M, Gadicherla AK, Culot M, Cecchelli R, Bultynck G, Leybaert L: Endothelial calcium dynamics, connexin channels and blood-brain barrier function. Prog Neurobiol 2013;108:1-20.

-36 Arveschoug A, Christensen KS: Constitutive expression of phVEGF165 after intramuscular gene transfer promotes collateral vessel development in patients with critical limb ischemia. Circulation 1999;99:2967b2968.

-37 Ai F, Chen M, Li W, Yang Y, Xu G, Gui F, Liu Z, Bai X, Chen Z: Danshen improves damaged cardiac angiogenesis and cardiac function induced by myocardial infarction by modulating HIF-1 $\alpha$ VEGFA signaling pathway. Int J Clin Exp Med 2015;8:18311-18318.

38 Lavine KJ, Kovacs A, Weinheimer C, Mann DL: Repetitive myocardial ischemia promotes coronary growth in the adult mammalian heart. J Am Heart Assoc 2013;2:e000343.

39 Luo Q Guo D, Liu G, Chen G, Hang M, Jin M: Exosomes from MiR-126-overexpressing adscs are therapeutic in relieving acute myocardial ischaemic injury. Cell Physiol Biochem 2017;44:2105-2116.

-40 Liu Y, Yang X, Maureira P, Falanga A, Marie V, Gauchotte G, Poussier S, Groubatch F, Marie PY, Tran N: Permanently hypoxic cell culture yields rat bone marrow mesenchymal cells with higher therapeutic potential in the treatment of chronic myocardial infarction. Cell Physiol Biochem 2017;44:1064-1077.

-41 Liu J, Wu P, Wang H, Wang Y, Du Y, Cheng W, Xu Z, Zhou N, Wang L, Yang Z: Necroptosis induced by AdHGF activates endogenous C-Kit+ cardiac stem cells and promotes cardiomyocyte proliferation and angiogenesis in the infarcted aged heart. Cell Physiol Biochem 2016;40:847-860.

42 Comerota AJ, Throm RC, Miller KA, Henry T, Chronos N, Laird J, Sequeira R, Kent CK, Bacchetta M, Goldman C, Salenius JP, Schmieder FA, Pilsudski R: Naked plasmid DNA encoding fibroblast growth factor type 1 for the treatment of end-stage unreconstructible lower extremity ischemia: preliminary results of a phase $\mathrm{i}$ trial. J Vasc Surg 2002;35:930-936.

43 Gaffney MM, Hynes SO, Barry F, O’Brien T: Cardiovascular gene therapy: current status and therapeutic potential. Br J Pharmacol 2007;152:175-188. 